\title{
Research Paper \\ Effectiveness of Emotionally Focused Couple Therapy on Cohesion, Adaptability, Emotional Intimacy and Quality of Communication in the Parents after the Birth of the First Child
}

\author{
Sayed Omid Sotoodeh Navroodi ${ }^{1}$, Mojgan Nicknam ${ }^{* 2}$, Azam Fatahi Andabil ${ }^{2}$ \\ 1. Ph.D. Student of Counseling, Roodehen Branch, Islamic Azad University, Tehran, Iran \\ 2. Assistant Professor, Department of Counseling, Roodehen Branch, Islamic Azad University, Tehran, Iran
}

Citation: Sotoodeh Navroodi SO, Nicknam N, Fatahi Andabil A. Effectiveness of emotionally focused couple therapy on cohesion, adaptability, emotional intimacy and quality of communication in the parents after the birth of the first child. Quarterly Journal of Child Mental Health. 2020; 7(3): 1-13.

\section{http://dx.doi.org/10.52547/jcmh.7.3.2}

\section{A R T I C L E I N F O}

\section{Keywords:}

Emotionally focused couple therapy, cohesion, adaptability, emotional intimacy, quality of communication

Received: 12 Jun 2020 Accepted: 14 Sep 2020 Available: 24 Nov 2020

\section{A B S T R A C T}

Background and Purpose: After the birth of their first child, couples often become confused about becoming adaptable to their new living conditions and satisfying the need for emotional intimacy in line with the desired parenting style. Coping with the child-rearing problems and managing the caregiving responsibilities may make the marital relationship more complicated. This study aimed to investigate the effectiveness of emotionally focused couple therapy on cohesion, adaptability, emotional intimacy and quality of communication in couples after the birth of the first child.

Method: This research was a quasi-experimental study with control group pretest-posttest design. The statistical population included all the parents with a child under the age of 5 who was attending a kindergarten in Rasht during March to September 2019. The sample included 16 couples (8 in the experimental group and 8 in the control group) who were selected by convenience sampling and then randomly assigned to either the experimental or control group. The experimental group received nine 90-min sessions of emotionally focused couple therapy and the control group was put on the waiting list to receive the intervention. All participants were assessed at pretest and posttest stages through using the Adaptability and Cohesion Evaluation Scale III (FACESIII), (Olson et al., 1985), Personal Assessment of Intimacy in Relationships Scale (Schaefer \& Olson, 1981) and Quality of Communication between Couples (Khoshkam, 2006). Data were analyzed by analysis of covariance. Results: Findings showed that the emotionally focused couple therapy was positively effective on cohesion $(\mathrm{F}=500.492, \mathrm{P}<0.001)$, adaptability $(\mathrm{F}=231.225, \mathrm{P}<0.001)$, emotional intimacy $(\mathrm{F}=1362.482, \mathrm{P}<0.01)$ and quality of communication between the parents $(\mathrm{F}=244.444, \mathrm{P}<0.0001)$. Conclusion: Based on the results of this study, it can be concluded that emotionally focused couple therapy can improve the intimacy between the parents and increase their satisfaction with each other through influencing the effective communication style, developing the emotional bond, identifying beliefs and background of couples' attachment, understanding the relation between behavior and thoughts and emotions and developing realistic expectations about parenting, especially after the birth of the first child.

\footnotetext{
* Corresponding author: Mojgan Nicknam, Assistant Professor, Department of Counseling, Roodehen Branch, Islamic Azad University, Tehran, Iran.

E-mail addresses: Nickname.mojgan@gmail.com
} 


\title{
اثربخشى زوجدرمانى هيجانمدار بر بيوستغى، انطباقيذيرى، صميميت عاطفى، و كيفيت ارتباطى والدين بعد از تولد فرزند نخست
}

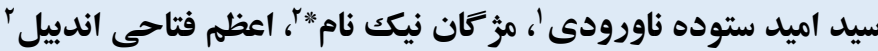 \\ ا. دانشجوى د كتراى مشاوره، واحد رودهن، دانشگاه آزاد اسلامى، تهران، ايران

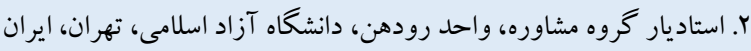

\begin{tabular}{|c|c|}
\hline جكيده & مشخصات مقاله \\
\hline زمينه و هدف: بعد از تولد فرزند نخست، زوجين براى سازش يافتگى با شرايط جديد زندگى خود و ارضاى نياز به صميميت عاطفى همگام & 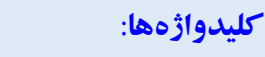 \\
\hline با سبك والدگرى مطلوب، به طور كلى دجار سردر گمى مى شوند. مديريت مشكلات مربوط به يرورش فرزند و وظايف مر اقبتى هر يك از & زوجدرمانى هيجانمدار، \\
\hline والدين، ممكن است باعث آشفته تر شدن روابط زناشويى شود. هدف اين يثزوهش، بررسى اثربخشى زوجدرمانى هيجانمدار بر ييوستگى، & 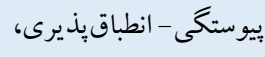 \\
\hline انطباقيذيرى، صميمت عاطفى، و كيفيت ارتباطى والدين بعد از تولد نخستين فرزند است. & 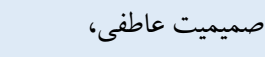 \\
\hline روش: روش اين يثوهش، نيمه آزمايشى باطرح ييش آزمون و يس آزمون با دو گروه آزمايش وگو اه بود. جامعه آمارى، شامل تمامى والدين & كيفيت ارتباطى \\
\hline داراى يكك فرزند زير ه سال بود كه در 9 ماه اول سال ^هץ| در مهدكودككهاى شهر رشت حضور داشتند. حجم نمونه شامل 19 زوج (A & \\
\hline زوج گروه آزمايش و ^زوج گروه گواه) از جامعه آمارى مذكور بود كه به شيوه نمونه گيرى در دسترس انتخاب شده و به طور تصادفى در & \\
\hline دو گروه گو اه و آزمايش جايدهى شدند. براى گروه آزمايش ه جلسه •9 دقيقهاى زوجدرمانى هيجانمدار انجام شد و گروه گو اه در نوبت & \\
\hline مداخله قرار گرفت. تمامى آزمودنى ها در طى دو مرحله ييش آزمون و يس آزمون با استفاده از يرسشنامهاى انطباقيذيرى و ييوستكى السون & \\
\hline و همكاران (ه1911)، ارزيابى شخصى صميمت شافر و السون (1911) و كيفيت ارتباطى زوجين (خوشكام، هرr|) مورد ارزيابى قرار گرفتند. & \\
\hline دادههاى جمع آورى شده نيز با تحليل كوواريانس، تجزيه و تحليل شدند. & \\
\hline 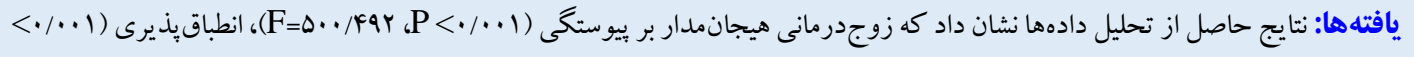 & \\
\hline 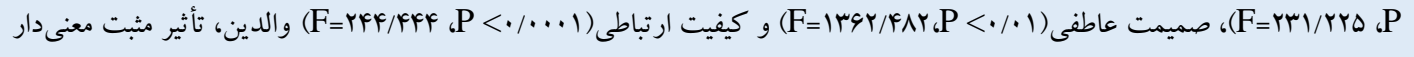 & \\
\hline داشته است. & \\
\hline نتيجه كيرى: بر اساس يافتهاى اين مطالعه مىتوان نتيجه گيرى كرد كه روش زوجدرمانى متمركز بر هيجان با تأثير بر سبك برقرارى ارتباط & 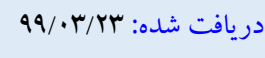 \\
\hline مؤثر، گسترش ييوند عاطفى، شناسايى اعتقادات و باو رها و ييشينه دلبستخى زوجين، دركى رابطه رفتار با افكار و هيجانها، و ايجاد انتظارات & 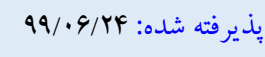 \\
\hline واقع بينانه درباره والدگرىى، به خصوص بس از تولد نخستين فرزند، موجب ارتقاو بهبود رضايتمندى و صميمت هر يكك از والدين مىشود. & 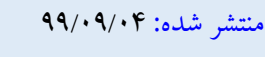 \\
\hline
\end{tabular}

* نويسنده مسئول: مز گان نيكنام، استاديار گروه مشاوره، واحد رودهن، دانشگاه آزاد اسلامى، تهران، ايران.

رايانامه: Nickname.mojgan@gmail.com 
بين زن و شوهر در مسائل مختلف و عـدم استفاده از روشهاى مناسب

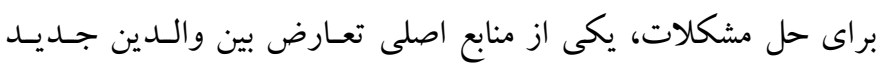

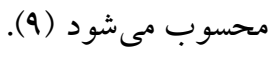

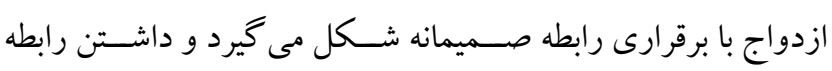

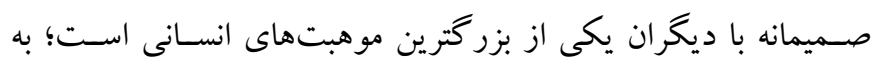

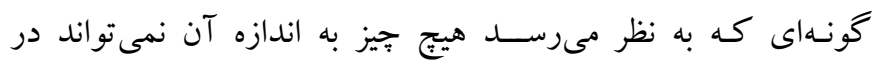

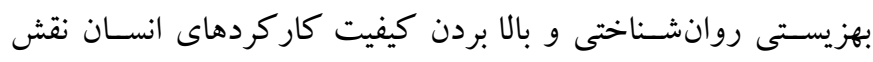

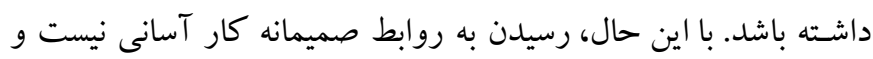

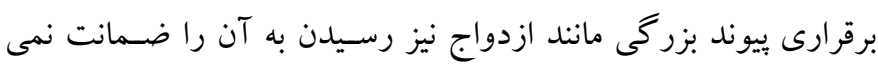

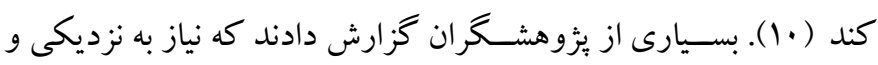

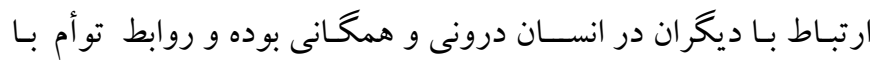

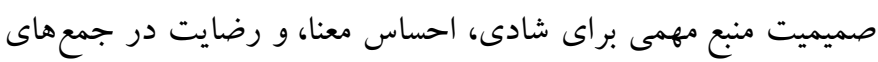

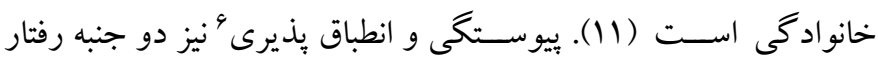

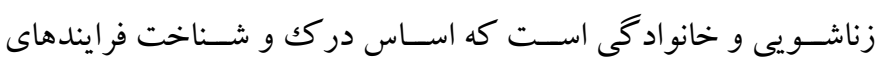

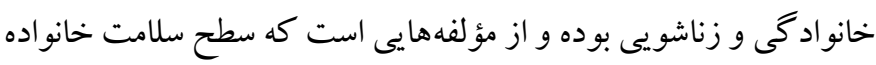

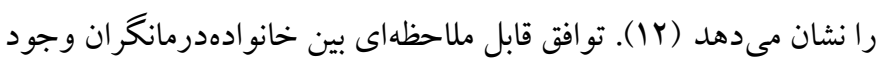

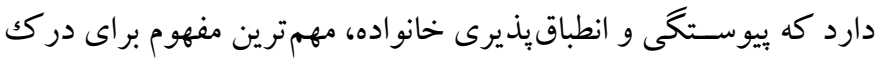

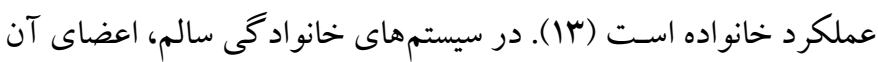

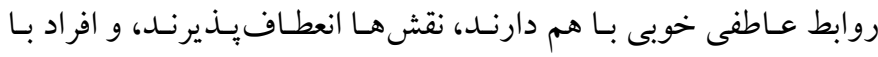

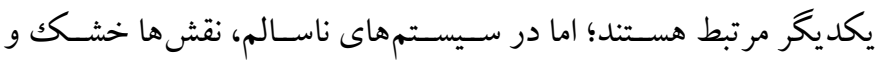

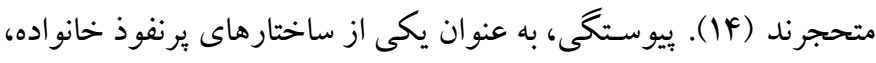

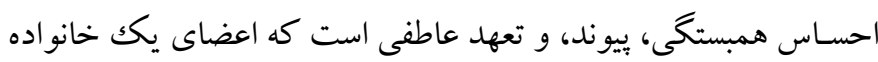

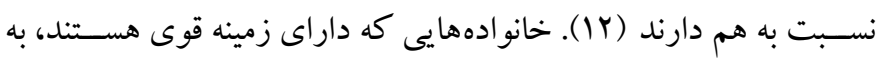

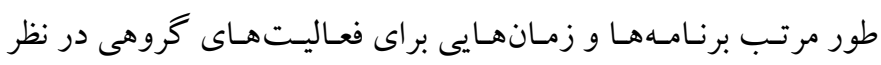

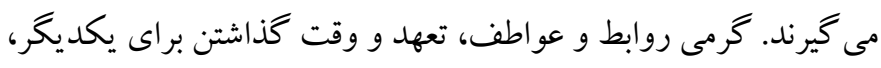

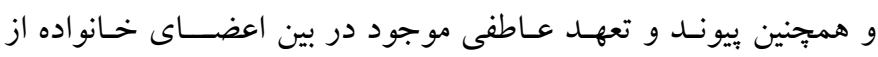

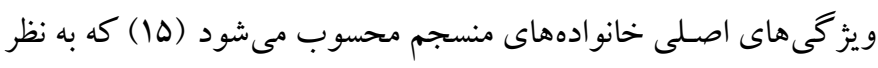

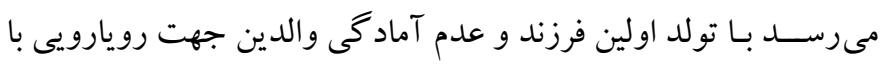

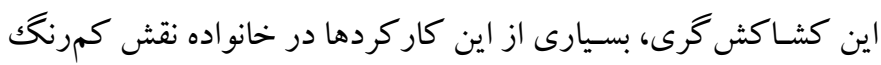

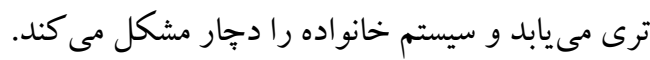

4. Marital adjustment

5. The quality of marital relationship

6. Cohesion and adaptability
مقلهم تولد فرزند، تكميل روياهاى والد شــدن و از سـويى ديخر، آغاز لحظات

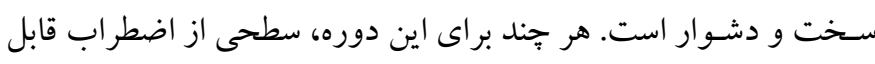

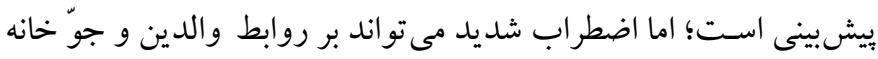

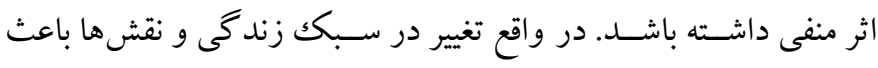

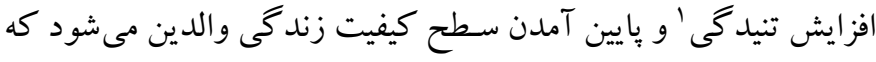

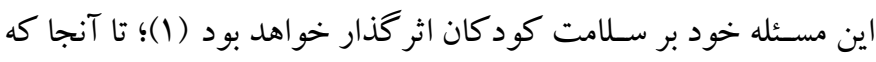

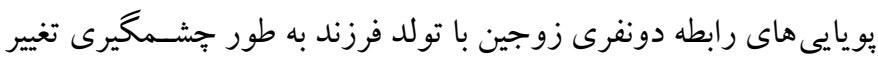

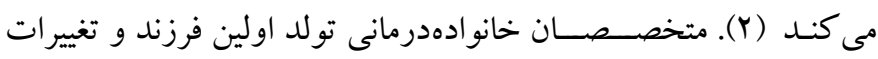

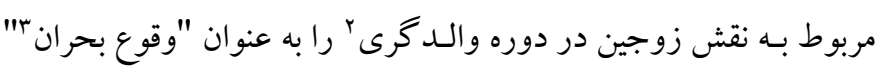

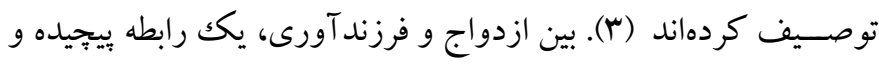

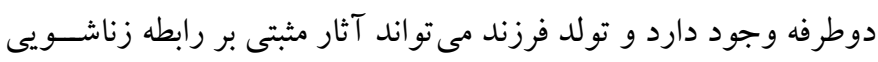

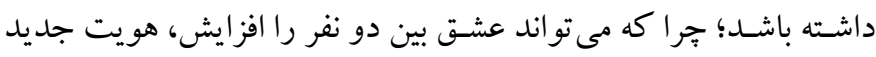
والد شدن را براى زوجين به همراه داشته باشد، و منبع رضايت شود (F).

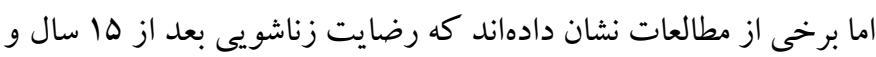

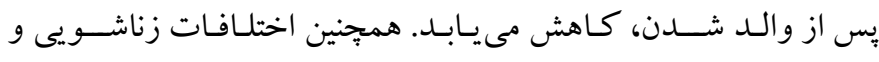

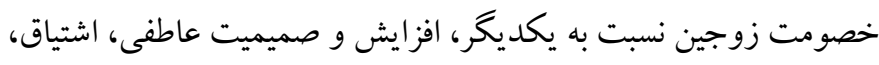
و رابطه جنسى و عاطفى، سير نزولى ييدا مى كند (Y و ه).

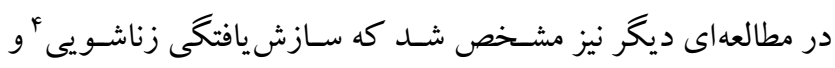

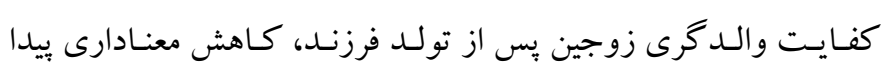
مى كند (9). هر جند اثرات تولد فرزند بر بهزيستى ذهنى والدين به بع بوامل

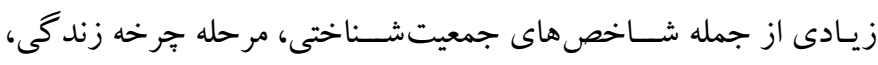

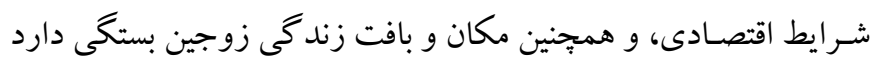

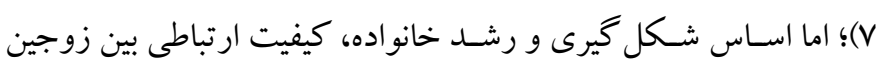

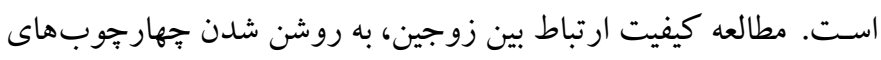

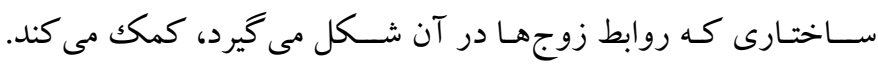

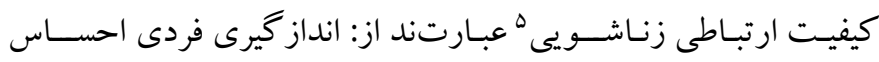

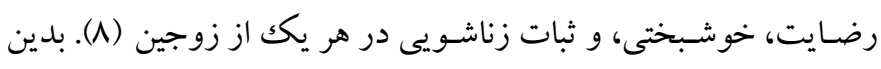

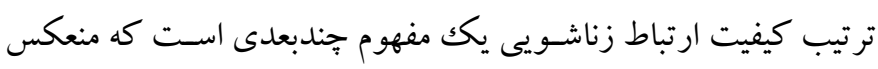

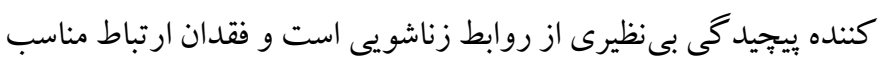

1. Stress

2. Parenting

3. Crisis 
زوجدرمـانى هيجـانمدار بر بخشـش و آشــتى، همبســتخى عاطفى، و

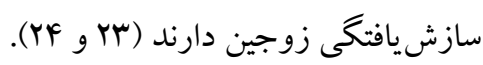

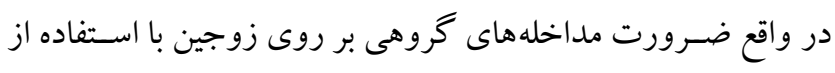

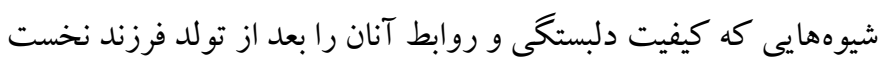

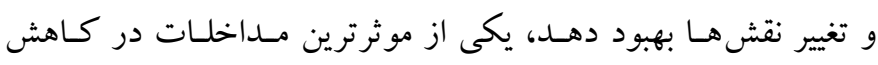

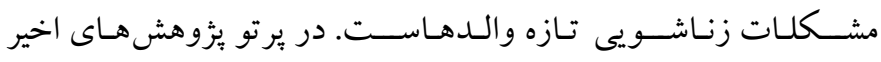

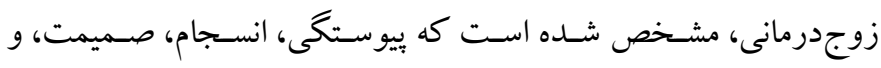

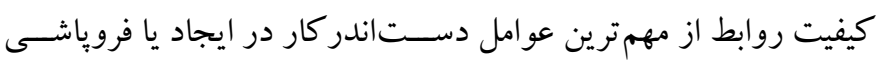

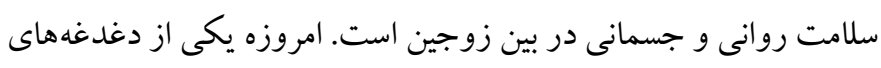

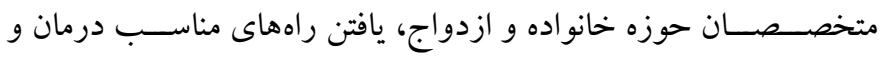

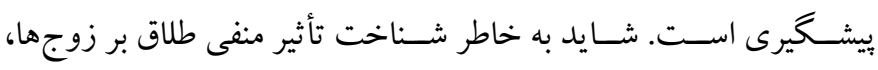

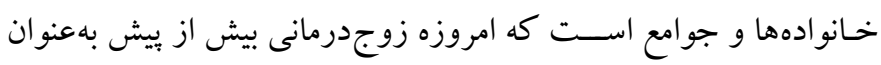

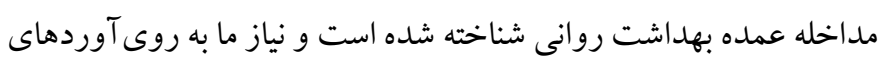
موثر و به طور تجربى حمايت شـده براى زوجدرمانى، مورد تأكيد است.

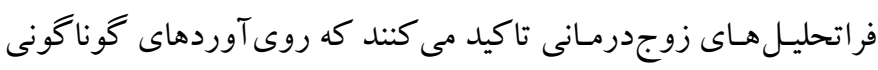

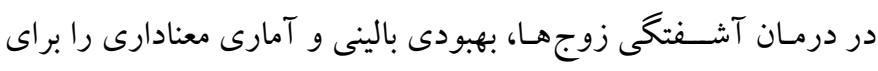

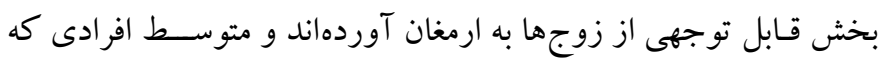

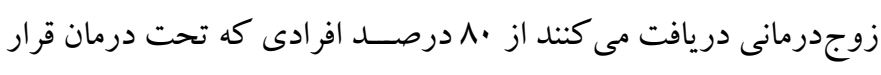

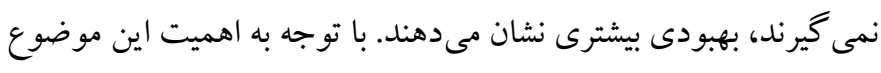

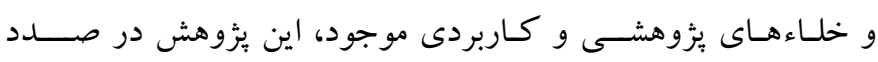

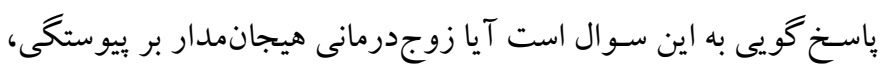

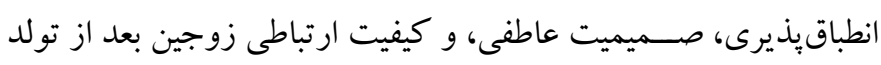

فرزند نخست، مؤثر است.

روش

الف) طرح هزؤهش و شـــ كت كنند كان: يُزوهش حاضـر يكك مطالعه

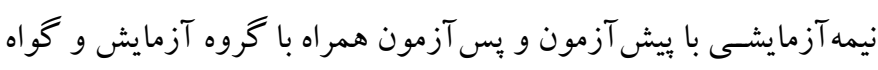

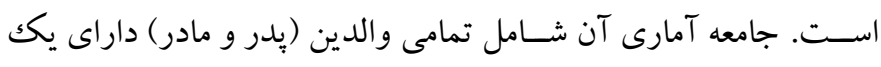

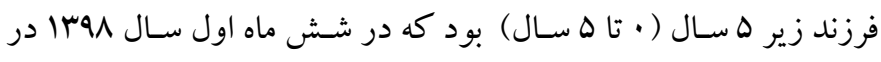

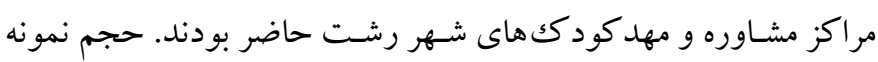

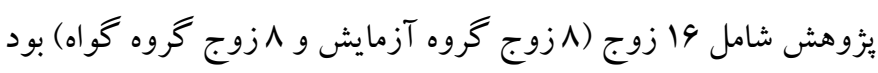

بـا وجود اينكـه مطـالعـات زيـادى نشــان دادهانــد بين تولــد فرزند و اختلـافات زناشـــيى رابطه وجود دارد، طرحها و مدلهاى درمانى كافى

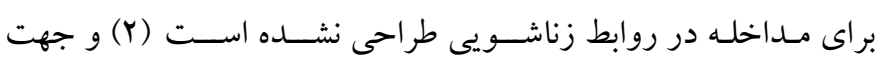

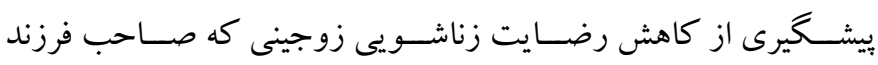

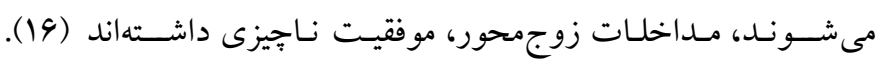
يزووهش ها نشان دادهاند كه مداخلات آموزشى بر ارتباطات زناشويى بعد

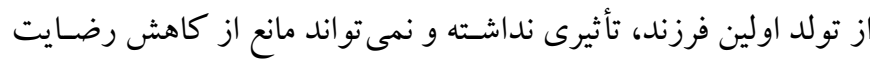

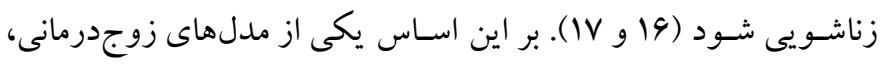

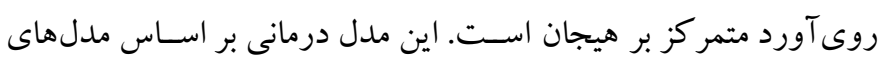

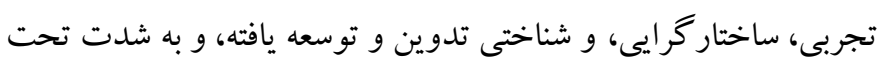

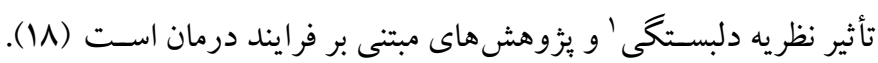

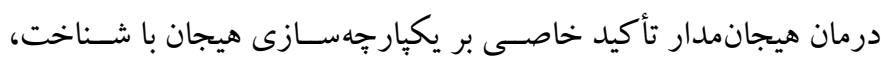

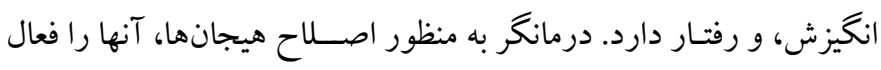

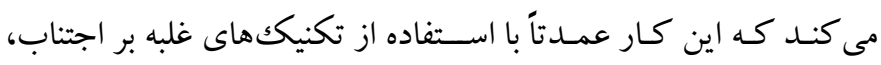
كـاهش رفتارهاى مختل كننده، و تســهيل شــــايط بهبود هيجانى، انجام

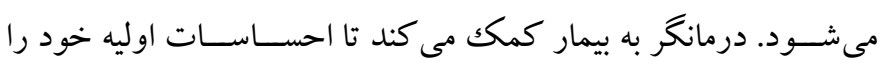

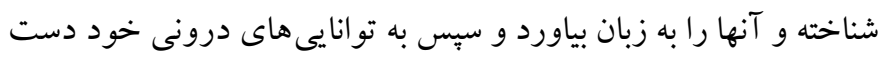

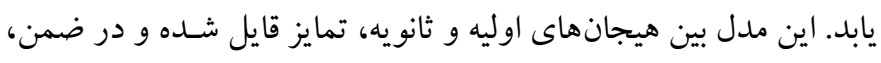

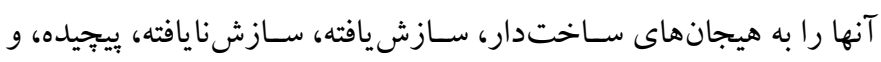

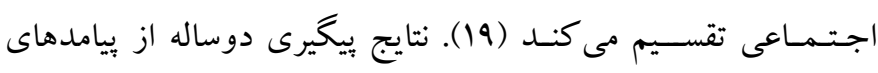

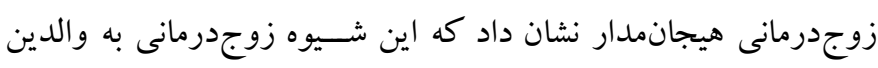

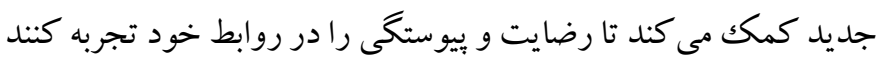

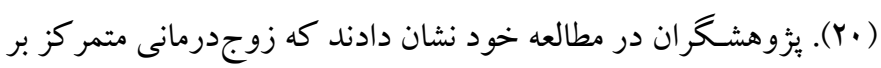

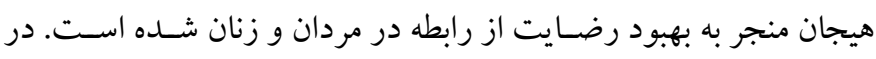
مطالعهاى ديخر مشـخص شــــ كه درمانهاى متمر كز بر هيجان تأثيرات

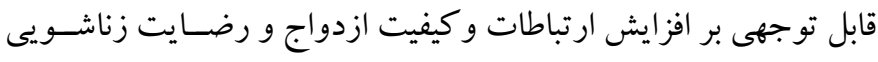

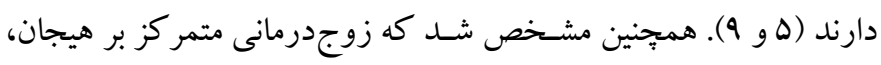

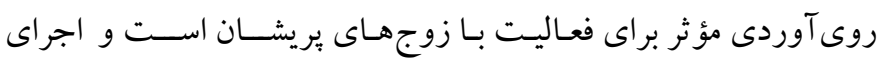
مداخله هاى زوجدرمانى براى والدين بر كيفيت رابطه آينده، تأثير مطلوب

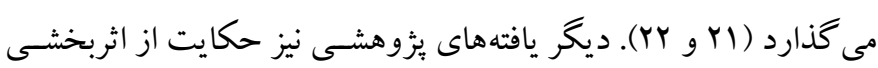


اعتبار (از نوع همسـانى درونى) مقياس بيوستخى و انطباق يذيرى خانو اده

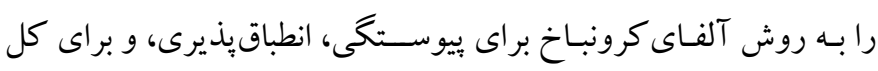

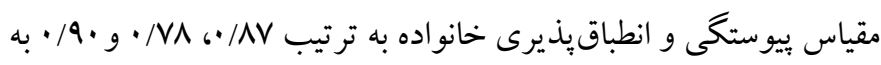

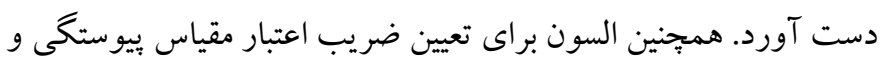

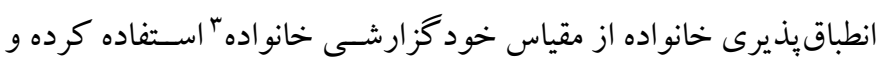

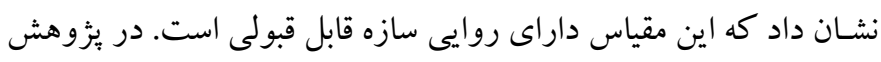

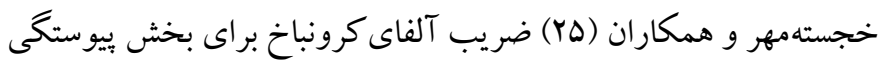

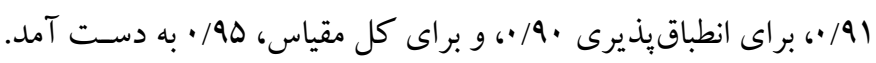

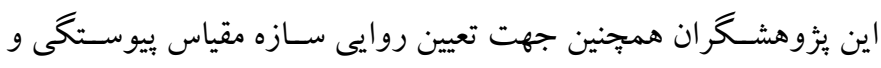

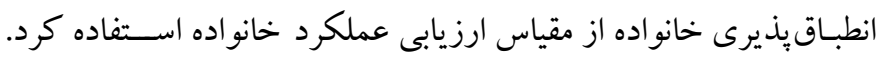

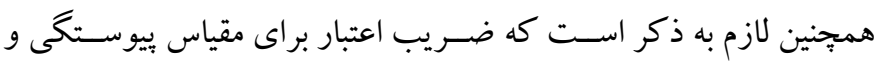

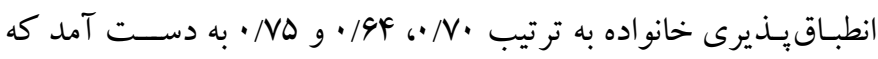

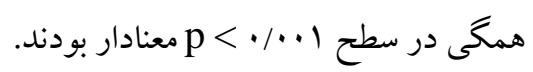

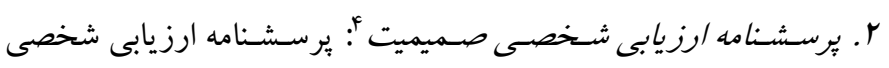

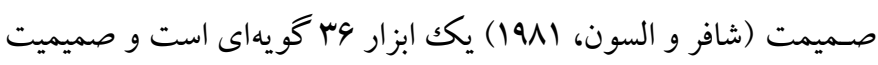
را در شـش بعد عاطفى، اجتماعى، جنسى، عقلانى، تفريحى، و عرفى در

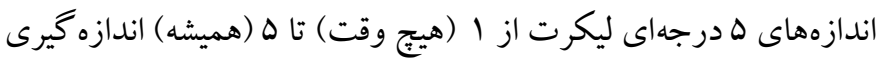

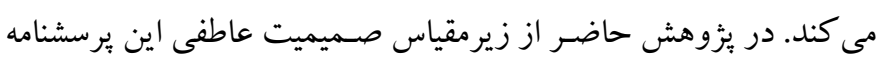

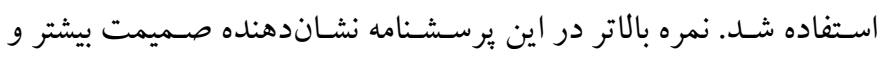
كسـب نمره پايين تر، حاكى از صـميمت كمتر اسـت. شافر و السون (Y4)

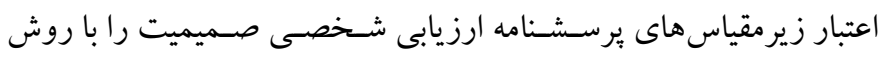

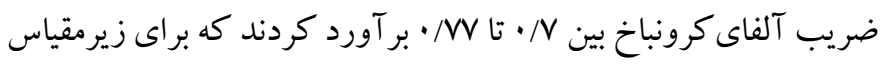

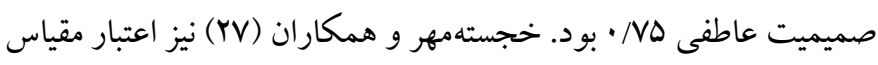

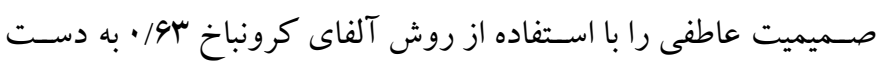

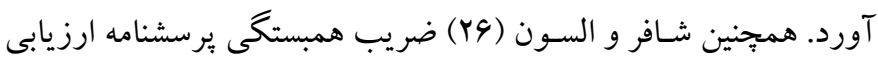

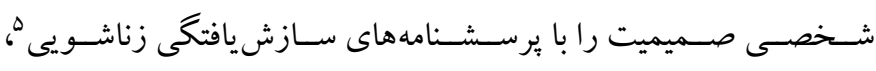

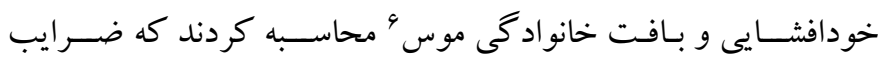

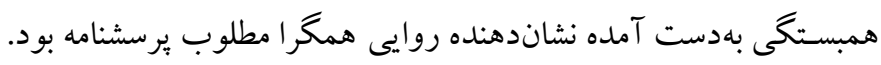

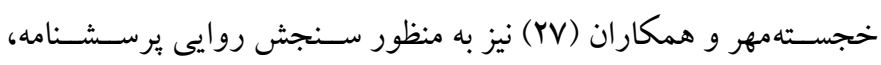

4. Personal assessing intimacy (PAI)

5. Marital adjustment (MA)

6. Moos family environment scale (MFES)
كه به شـيوه نمونه گيرى در دسـترس از بين والدين كود كان حاضسر مهل كودكك و مراكز مشـاوره شـهر رشت حضور داشتند و با توجه به شر ايط ورود و خروج از جـامعـه آمـارى مذكور انتخاب شـــند و به صــورت تصـادفى در دو گروه آزمايش و گواه جايدهى شـدند. شــرايط ورود به مطالعه عبارت بودند از: تحصيلات حداقل ديبلم، حداقل هفت سال سابقه زندكى مشـترك، نارضايتى از روابط زناشويى بر اساس گز ارش والدين، دارا بودن تنها يكك فرزند زير ه ســال، كســب نمره يكك انحراف معيار يايين تر در يرسـشـنامههاى مورد اسـتفاده در بخش ابزار، متعهد شــدن به حضور در تمام جلسات درمان به صورت زوجى. هميجنين شرايط خروج افرد نمونسه از بثزوهش عبـارت بودنـــ از: قرار داشــت در دورههـاى رواندرمانى يا روانيزشكى غير از دوره زوجدرمانى مربوط به اين مطالعه، تصـميم به جدايى والدين از يكديخر، ابتلا به اختلالهاى روانشناختى، و مصــرف مواد). براى گروه آزمـايش ه جلســهـ ·ه دقيقهاى زوجدرمانى هيجانمدار انجام شد و گرووه گواه در نوبت دريافت مداخله بعد از يايان مطالعهه، قرار كرفت. تمامى آزمودنىها در طى دو مر حله (ييش آزمون ـ يس آزمون) با استفاده از برسشنامه هاى ارزيابى انطباقيذيرى و بيوستخى خانواده، ارزيابى شــخصـى صــميمت، و كيفيت ارتباطى زوجين مورد بر برسى قرار كرفتند.

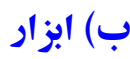

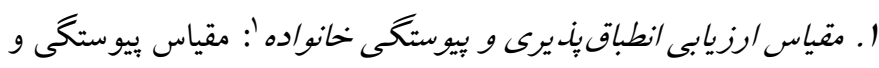

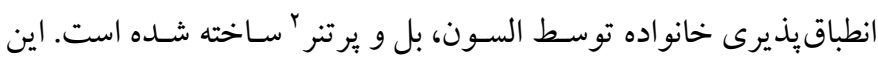

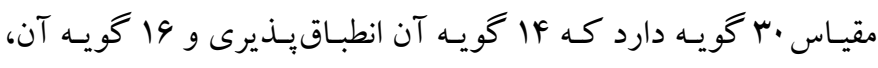
بيوستخًى را مى سـنجند. نمرههاى به دست آمده در ابعاد انطباقيذيرى و يبوستخى براى نشان دادن خانو ادههاى متعادل و نامتعادل در مدل حلقوى

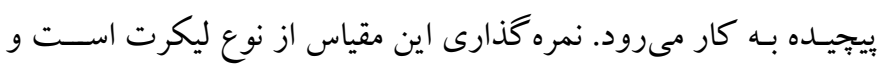
ياسخها از ا (تقريبأ هيج وقت) تا ها (تقريبأ هميشه) نمره كذارى مىشوند. حداقل نمره در مقياس بيوسـتخى و انطباقيذيرى خانواده، ·ب و حداكثر نمره آن •ها اسـت. نمرات بالا در اين مقياس نشـان مىدهد كه خانواده داراى عملكرد مطلوبى اســت و بـالعكس كســبـ نمرات يـايين در اين يرسـشـنامه نشـان دهنده عملكرد نامطلوب خانو اده اسـت. السـون ضريب

1. Family adaptability and cohesion evaluation scales (FACES-2)

2. Olson, Bell \& Portner

3. Self-report family inventory 
خوشـكام با آلفاى كرونباخ •9/ • گززارش شده است. خوشـكام همجنين

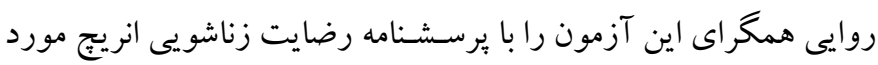

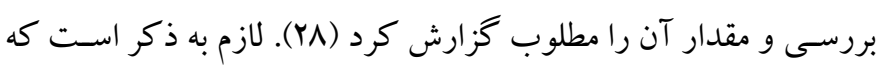

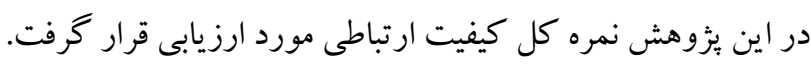

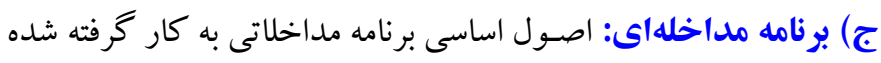

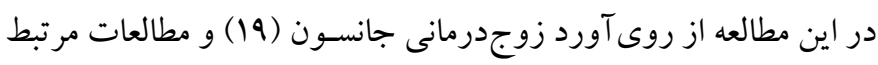

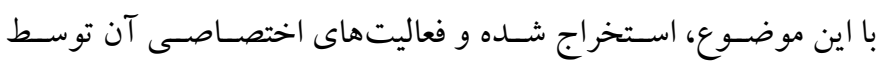

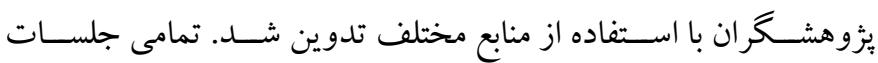

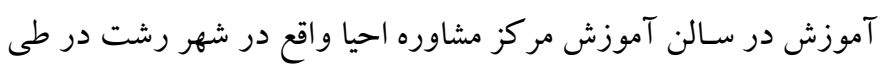

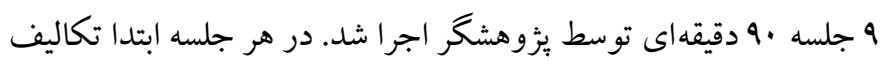

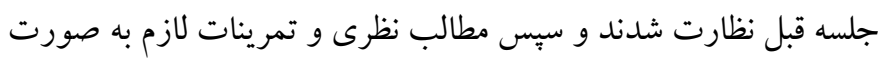
عملى و در نهايت تكاليف منزل براى جلسـهـ بعد به گروه مداخله، ارائه

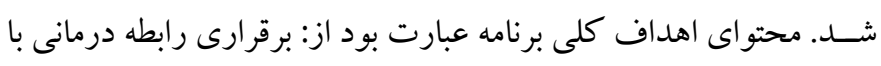

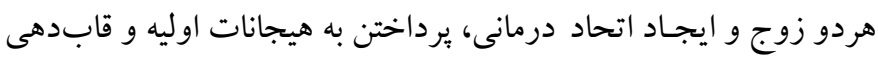

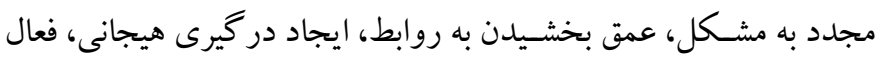

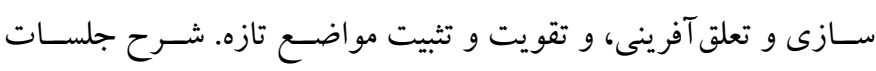
زوجدرمانى گروهى با روى آورد هيجانمدار در جدول آرول آمده است.
ضـريب همبستخى آن را با مقياس صسميميت واكر و تامٍِسون' محاسـبه

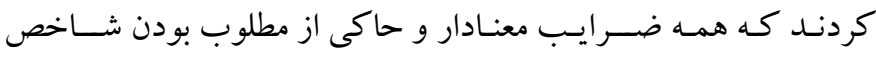
روانسنجى روايى برسشنامه بودند.

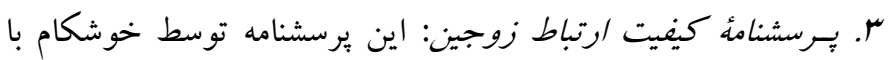

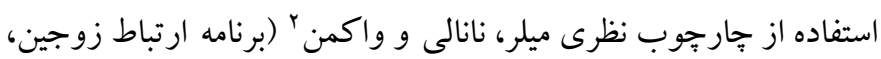

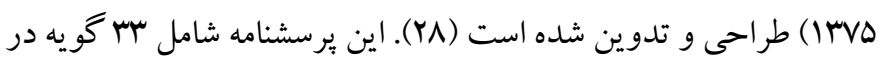
جهار حيطه است. حيطه نخست با نام توجه كردن به خود داراى هـ گويه،

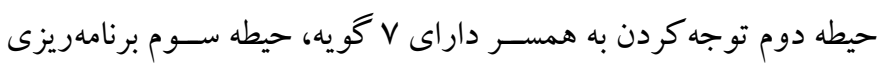

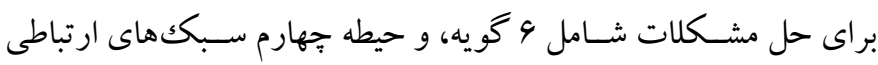

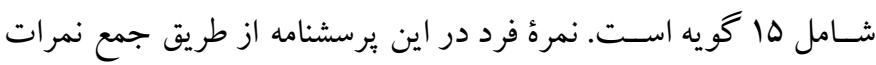

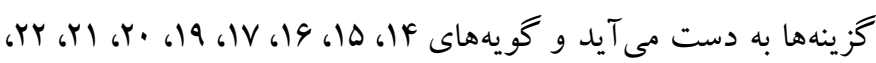

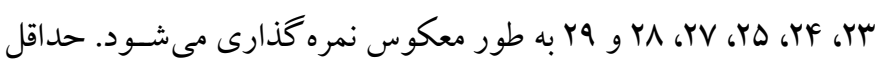

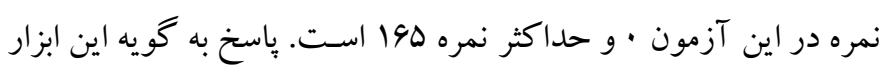

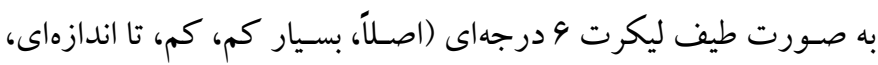

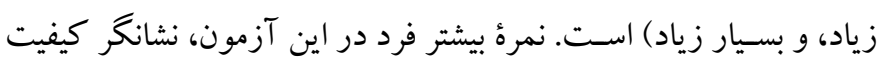

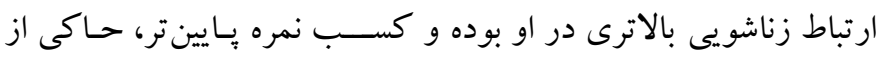

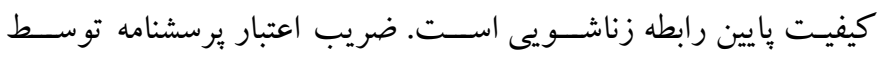

\section{جدول ا: خلاصه جلسات مداخله زوجدرمانى هيجانمدار ويزه والدين}

\begin{tabular}{|c|c|}
\hline اهداف و محتواى جلسات & جلسات \\
\hline 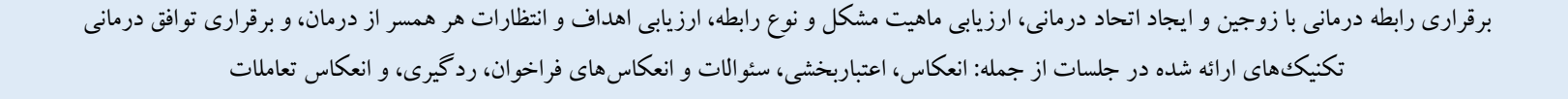 & $r$ \\
\hline 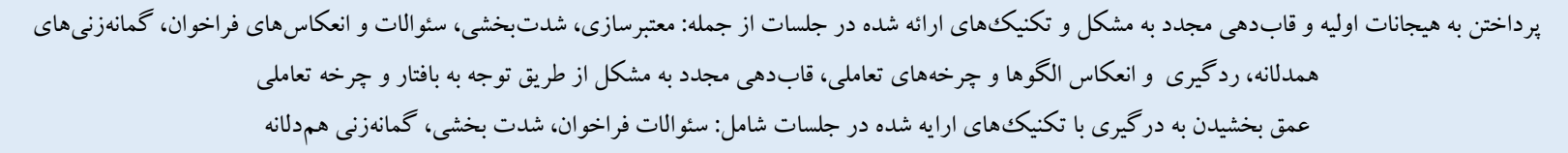 & 4,0 \\
\hline 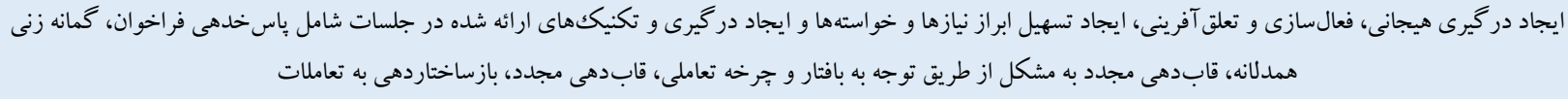 & $\wedge, \vee$ \\
\hline تقويت و تثبيت مواضع تازه، يكهارجه سازى تغييرات درمانى با زندگى واقعى، با تكنيكهاى ارائه شده در جلسات شامل انعكاس تغيرات كنونى، اعتباربخشى به پِاسخها و الكوهاى & 9 \\
\hline
\end{tabular}

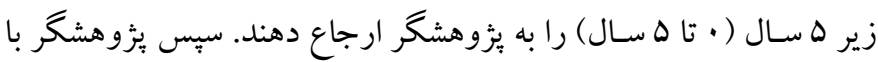

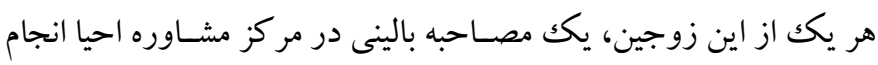

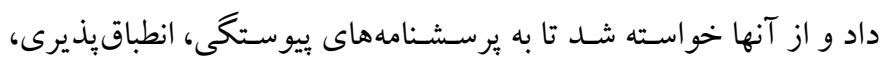

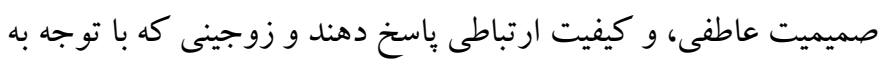

2. Miller, Nanaly \& Wakman

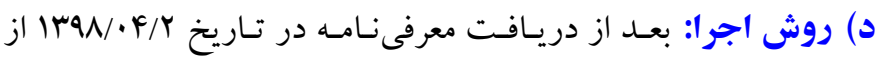

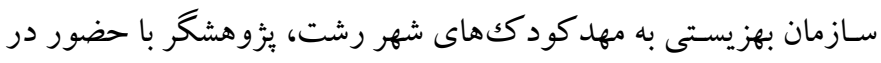

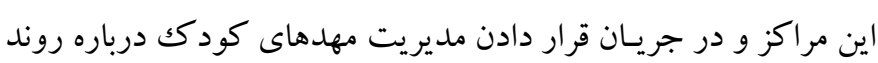

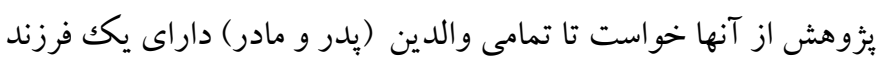


استففاده شده و كاملا محرمانه باقى مىماند. تحليل دادهها نيز با استفاده از

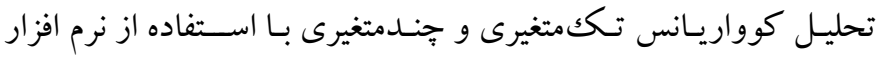

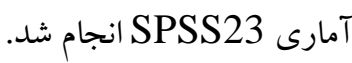

يافته ها ميانخين و انحر افاســاندارد نمرات بيش آزمون - بِ بـ آزمون متغيرهاى

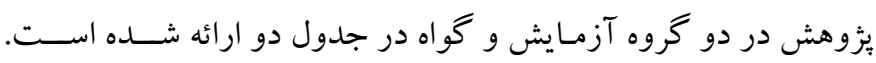

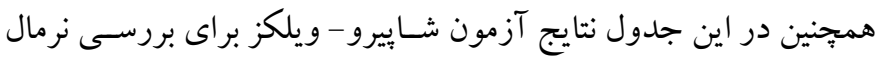

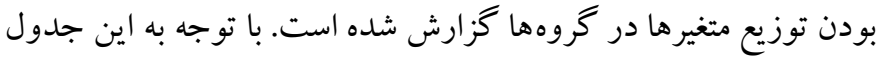

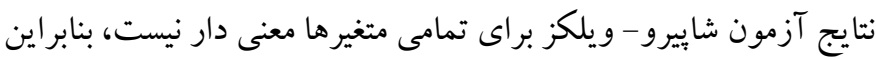

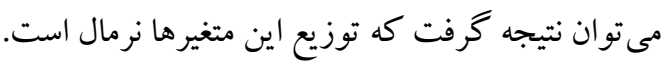

مصساحبه بالينى، سـطح رضـايت زناشـويى بايين و نيز نمره يكك انحراف

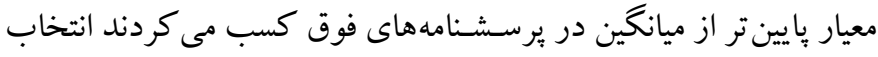

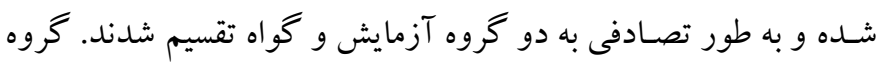

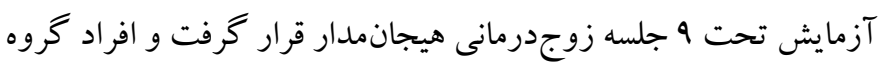
كواه هيج درمانى دريافت نكرد و در فهرست انتظار دريافت مداخله قرار

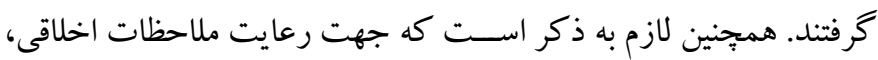

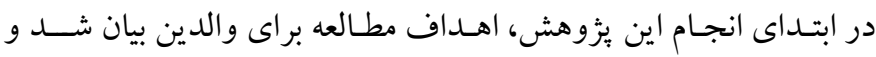

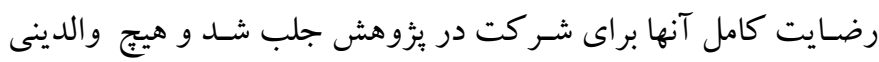

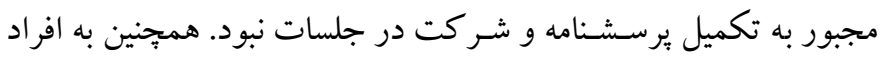

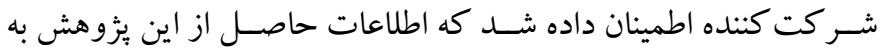
صـورت گروهى مورد تحليل قرار گرفته و براى توليد مسـتندات علمى

جدول r: شاخصهاى توصيفى نمرات ييش آزمون - يس آزمون در دو كروه آزمايش و كواه (تعداد: rr)

\begin{tabular}{|c|c|c|c|c|c|c|}
\hline $\mathbf{P}$ & شاييرو-ويلكز & انحر افاستاندارد & ميانكين & كروه & وضعيت & متغير \\
\hline.$/ .91$ &.$/ 9.9$ & r/rq & $r \cdot / \cdot$ & آزمايش & \multirow{2}{*}{ ي بيش آزمون } & \multirow{4}{*}{ انطباقيذيرى } \\
\hline.$/ 19$. &.$/ 919$ & $r / r$. & $r \cdot / r v$ & كواه & & \\
\hline - / raY & - / & $1 / \wedge 9$ & $r g / r v$ & آزمايش & \multirow{2}{*}{ يَ آزمون } & \\
\hline.$/ . \Delta \Delta$ & $\cdot / A \Delta F$ & r/aF & $r \cdot / \Delta 9$ & كواه & & \\
\hline - /ror & ./941 & I/Ar & $r \Delta / F r$ & آزمايش & \multirow{2}{*}{ ييش آزمون } & \multirow{4}{*}{ يوستخى } \\
\hline •/rTs & ./arq & $1 / \Delta 9$ & $r \Delta / \wedge 1$ & كواه & & \\
\hline$\cdot / \cdot v 1$ & •/^९४ & $1 / 11$ & $F \cdot / \Delta 9$ & آزمايش & \multirow{2}{*}{ پِ آزمون } & \\
\hline$\cdot / r r$. &.$/ 949$ & $1 / r \Delta$ & $r \Delta / \Lambda V$ & كواه & & \\
\hline ./1rq &.$/ 91 \%$ & $1 / 49$ & $1 \cdot / \mathrm{AV}$ & آزمايش & \multirow{2}{*}{ بيش آزمون } & \multirow{4}{*}{ سميمت عاطفى } \\
\hline.$/ \Delta F$ & . AVG & $1 / 41$ & $11 / \cdot \cdot$ & كواه & & \\
\hline.$/ . \Delta \wedge$ & -/AVa & ./Ar & $10 / 1 \wedge$ & آزمايش & \multirow{2}{*}{ يس آزمون } & \\
\hline$\cdot / .91$ & $\cdot / 199$ &.$/ 99$ & $1 . / 94$ & كواه & & \\
\hline$\cdot / N r \Lambda$ &.$/ 994$ & $r / 94$ & $\Delta V / a r$ & آزمايش & \multirow{2}{*}{ يِيش آزمون } & \multirow{4}{*}{ كيفيت ارتباطى } \\
\hline.$/ 1.9$ & $\cdot / 9 \cdot 1$ & $r / 9$. & $\Delta N / \Delta G$ & كواه & & \\
\hline . rar &.$/ 941$ & $r / M$ & $v \cdot / N \mid$ & آزمايش & \multirow{2}{*}{ بֶ آزمون } & \\
\hline$\cdot / 494$ & . & $r / Y F$ & $\Delta N / T Y$ & كواه & & \\
\hline
\end{tabular}

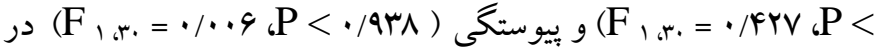

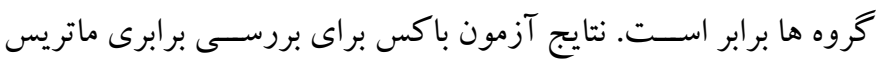

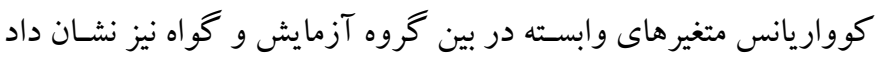

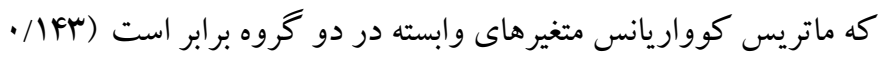

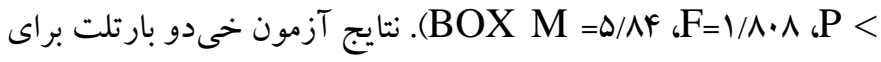
بررسـى كرويـت يـا معنى دارى رابطهـ بين مؤلفـهــاى انطبـاقيــيرى و

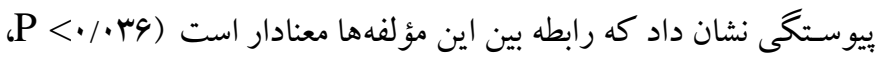

براى بررسى تأثير زوجدرمانى هيجانمدار بر مؤلفه هاى انطباقيذيرى

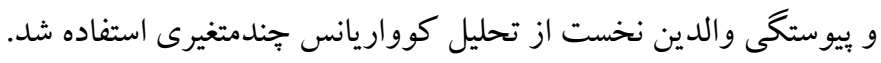

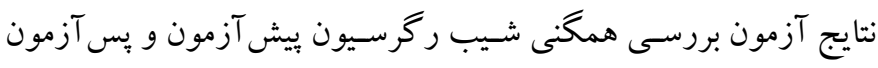

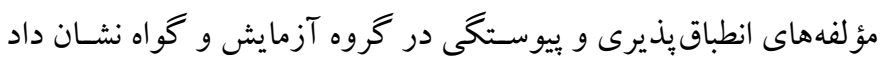

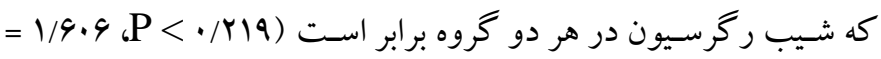
F F r.V وابسته در گروهها نشان داد كه واريانس مولفههاى انطباق يذيرى ( 


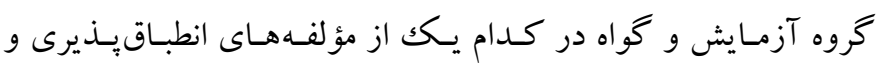

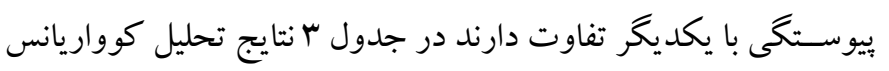
جندمتغيرى كزارش شده است. d.f=ه

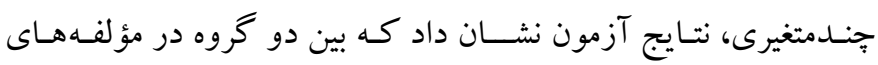

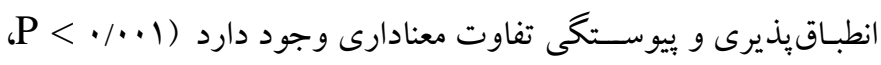

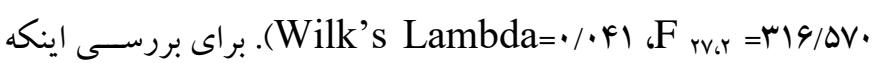

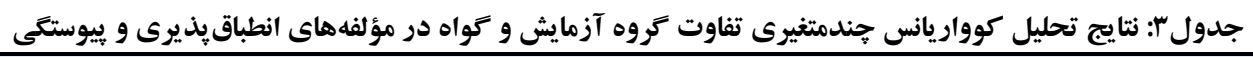

\begin{tabular}{|c|c|c|c|c|c|c|c|}
\hline ضرايب اتا & سطح معنادارى & $\mathbf{F}$ & ميانكين مجذورات & درجه آزادى & مجموع مجذور & منبع & متغير \\
\hline.$/ 11 r$ & $\cdot / \cdot \mathrm{vl}$ & $r / \Delta r$. & $F / . q F$ & 1 & $F / . q F$ & هميراش & \\
\hline \multirow[t]{2}{*}{ - /A9r } & $\cdot / \cdot 1$ & rMI/rYSO & rEN/ITF & 1 & TEN/ITK & عضويت گروهى & انطباقيذيرى \\
\hline & & & $1 / 19$ & rA & $r Y / 49 q$ & خطا & \\
\hline$\cdot / \wedge \Delta$ &.$/ \cdot 11$ & $q / T \Delta F$ & r/VVF & 1 & r/VVF & هميراش & \\
\hline \multirow[t]{2}{*}{$\cdot / Q F V$} & $\cdot / \cdot 1$ & $\Delta \cdot . / 4 q Y$ & YIN/FAD & 1 & YIN/FAD & عضويت گروهى & ييوستخى \\
\hline & & &.$/ F T V$ & YA & IYTrYT & خطا & \\
\hline
\end{tabular}

براى بررسى اثربخشى زوجدرمانى هيجانمدار بر صسميميت عاطفى والـدين از تحليـل كوواريانس تككمتغيرى اســفاده شــــ. نتايج آزمون بررسسى همخنى شـيب ركرسـيون ييش آزمون و يس آزمون صسميميت عاطفى در گروه آزمايش و كواه، نشان داد كه شيب ركرسيون در هر دو

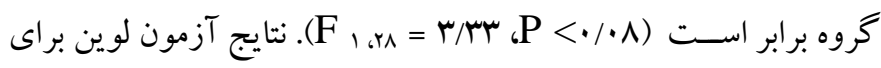
بررسى همخنى واريانس متغير وابسته در گرووهها نشـان داد كه واريانس

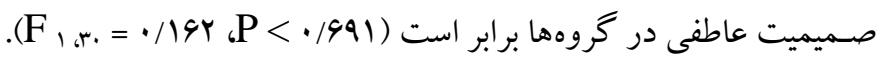
در جـدول \& نتايج تحليل كوواريانس تككمتغيرى براى بررسـى تفاوت كروه آزمايش و كواه در بيش آزمون با يس آزمون متغير صميمت عاطفى نسي

كز ارش شده است.

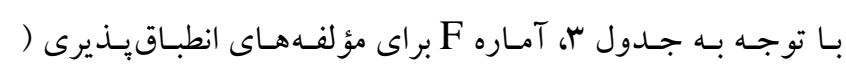
ه معنىدار مىباشـد. اين يافتها نشـانكر آن هسـتند كه بين كروهها در اين مؤلفهها تفاوت معنادارى وجود دارد. نتايج بررسى ميانگين هاى تصحيح

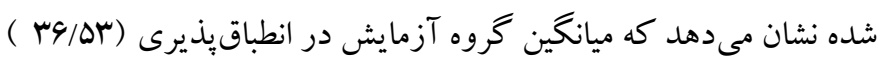

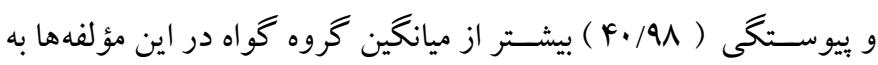

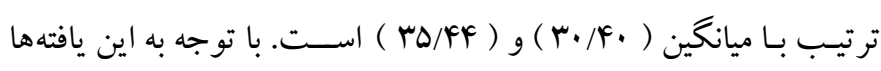
مى توان كفت كه زوجدرمانى هيجانمدار موجب افزايش انطباق يذيرى و بيوستگى والدين بعد از تولد فرزند نخست مى شود. همجنين اندازه اثر در

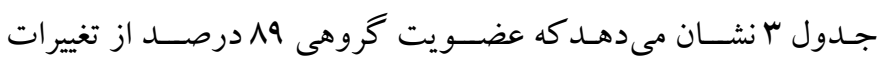
انطباقيذيرى و وf درصد از واريانس بيوستكى را تبيين مى كند.

جدول ع: نتايج تحليل كوواريانس تكمتغيرى براى بررسى تفاوت كروه آزمايش و كواه در صميمت عاطفى مئى

\begin{tabular}{|c|c|c|c|c|c|c|}
\hline اندازه اثر & $\mathbf{P}$ & $\mathbf{F}$ & ميانكين مجذورات & Df & مجموع مجذور & منبع \\
\hline$\cdot / \Delta \Delta r$ & $\% / \cdot 1$ & $r \Delta / v q v$ & $\mid F V / N D F$ & 1 & IFV/ADF & هميراش \\
\hline \multirow[t]{2}{*}{$\cdot / 9 \vee 9$} &.$/ \cdot 1$ & ITGY/FAY & $\Delta G Y V / F q V$ & 1 & $\Delta G Y V / F q V$ & عضويت گروهى \\
\hline & & & $r / l r$. & rq & $119 / \mathrm{VA}$. & خطا \\
\hline
\end{tabular}

اندازه اثر 9V/ • نيز نشـان مى دهد كه اين تفاوت در جامعه بزرك اسـت. نتـايج تحليل كوواريانس نشــان داد كه ميانخين تصـحيح شــده گرووه

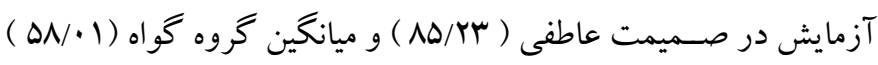

بـا توجسه بـه جـدول F F آمـاره F صــميمست عـاطفى در يس آزمون

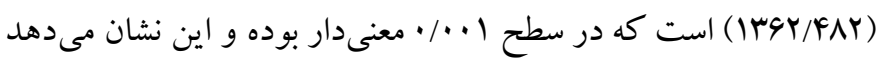
كه بين دو گرووه در ميزان صسميمت عاطفى تفاوت معنى دار وجود دارد. 


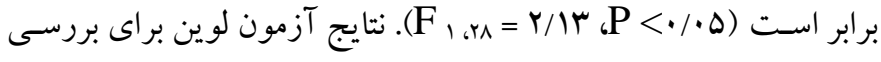

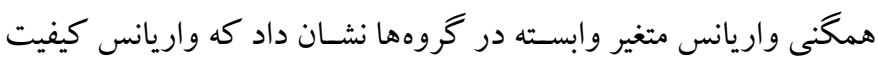

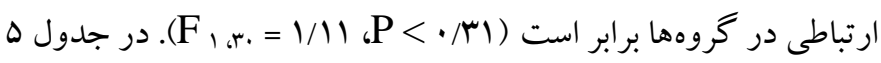

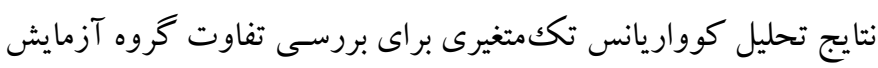

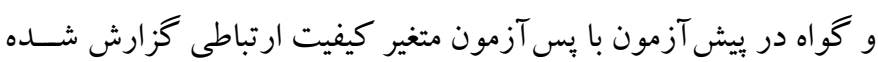

است.

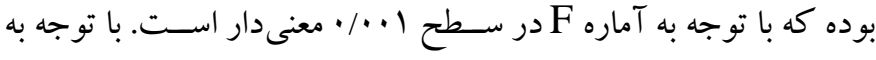

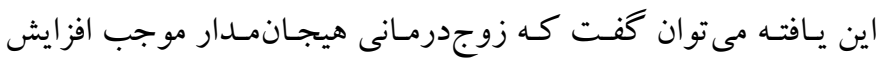
صميمت عاطفى والدين نخست مى شود. براى بررسـى اثربخشـى زوجدرمانى هيجانمدار بر كيفيت ارتباطى

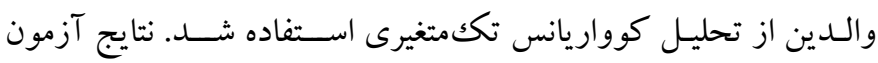

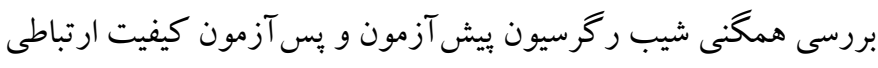

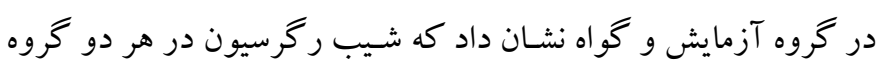

جدوله: نتايج تحليل كوواريانس تكمتغيرى براى بررسى تفاوت كروه آزمايش و كواه در كيفيت ارتباطى

\begin{tabular}{|c|c|c|c|c|c|c|}
\hline اندازه اثر & $\mathbf{P}$ & $\mathbf{F}$ & ميانكين مجذورات & Df & مجموع مجذور & منبع \\
\hline ./Irו & $.1 .4 \Delta$ & $F / r V V$ & $r F / \Delta \cdot V$ & 1 & $Y F / \Delta \cdot V$ & همبراش \\
\hline \multirow[t]{2}{*}{$\cdot / 1911$} & $\cdot \cdots \cdots 1$ & YFF/FFF & IrGA/VV. & 1 & IrGN/VV. & عضويت گروهى \\
\hline & & & $\Delta / 9 .$. & rq & $19 \% / \% \wedge 9$ & خطا \\
\hline
\end{tabular}

زوجين در كروه آزمايش شــده كه تأكيدى بر مؤثر بودن اين روى آورد درمانى در حل مشكلات زناشويى است. بر اسـاس روى آورد جانسـون (19) زوجدرمانى هيجانمدار با شـناسـايى جرخه دلبستِكى و كشـف نيازهاى اسـاسى زوجين، به بازسازى موقعيت جديد و بيان احســاســات زيربنايى و ارائه راهحل هاى جديد مى يردازد. زوجدرمانى هيجانمدار زمينه مناسبى براى كشف و منظم كردن هيجانات آشـفته ناشـى از دلبسـتكى هاى شـكل گرفته از زمان تولد تا بزر كسـالى اسـت. در اين شيوه درمانى، درمانكر به هر يكك از زوجها براى كسترش و سازماندهى درونى خودش كمكك مى كند و ابراز اين تجربه دربردارنده يكك شيوه جديد عرضه خود و يكك راهكار جديد براى برقرارى رابطه با

$$
\text { ديخرى مى شود. }
$$

تأكيد بر هيجان، عامل اساسى تغيير در زوجدرمانى است. زوجدرمانى

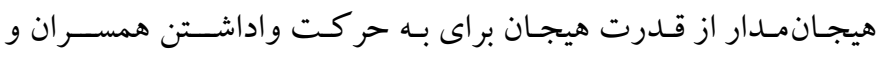
برانگيختن بِاسخهاى جديد در تعاملات اساسى و مكررى استفاده مى كند كه باعث رقص رابطه زوجين مىشـود. هيجان باعث ياسخ هاى اصلى در روابط نزديكك شده و آنها را سازمان مىدهد. نتيجه به دست آمده در اين يثزوهش را مى توان بر اساس ديدگاه جانسون و همكاران (19) و مطالعات ويتنبورن و همكـاران (ه)، وازهـاييلى و ريوايس (9)، ولج و همكـاران (Y) و فليب و همكاران (YY) اين گونه تبين كرد كه اين شيوه درمان به
بـا توجسه بـه جـدول ه آمـاره F كيفيـت ارتبـاطى در بس آزمون است كه در سطح l (IMN/VV•) كـه بين دو كروه در ميزان كيفيـت ارتبـاطى تفاوت معنىدار وجود دارد.

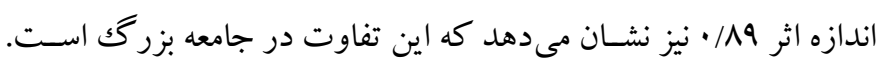
نتـايج تحليل كوواريانس نشــان داد كه ميانگين تصــحيح شــده گروه

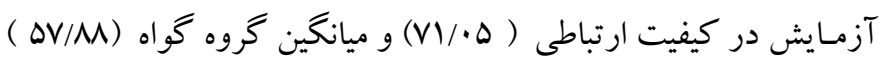

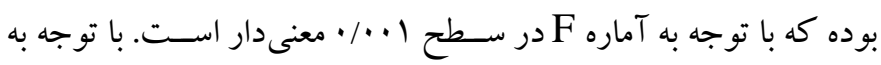

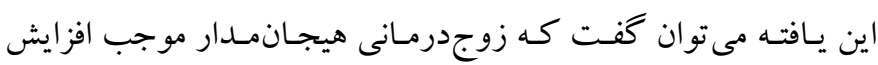
كيفيت ارتباطى والدين بعد از تولد فرزند نخست مى شود.

\section{بحث و نتيجه تيرى} يزوهش حاضــر با هدف بررسـى اثربخشـى زوجدرمانى هيجانمدار بر ييوسـتِى و انطباق يذيرى، صسميمت عاطفى، و كيفيت ارتباطى زوجين بعد از تولد فرزند نخسـت انجام شـــ. نتايج تحليل كوواريانس نشـان داد

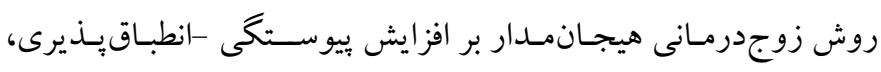
صـميميت عاطفى، و كيفيت ارتباطى زوجين مؤثر بوده است. اين يافته با نتايج يزٔوهشهاى كذشـته مبنى بر اثربخشـى زوجدرمانى هيجانمدار بر رضـايت زناشـويى، كيفيت ارتباطى، و صسميمت عاطفى زوجين همسـو

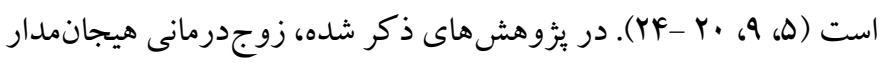
منجر بـه افز ايش ابعـاد ييوســــى - انطبـاقيذيرى، صــميمت، و ارتباط 
انتظـارات واقع بينـانهه در مورد والـدگرى در زوجين، آموزش والـدگرى

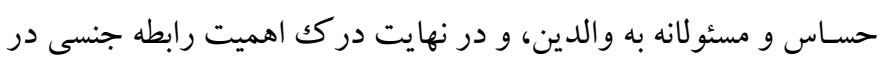

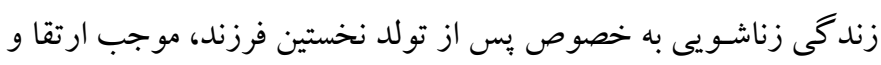
بهبود رضايتمندى تازه و الدها شده است.

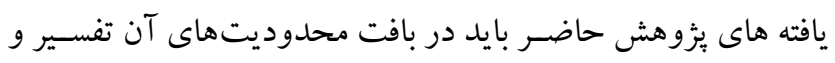

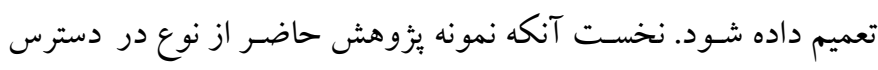

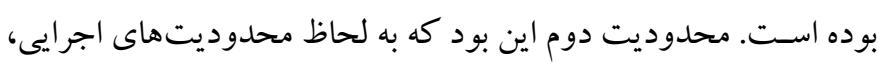

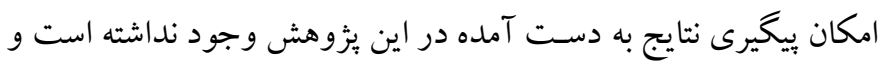

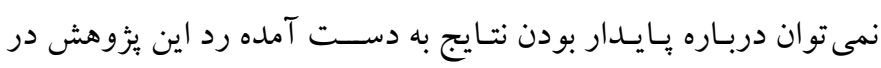

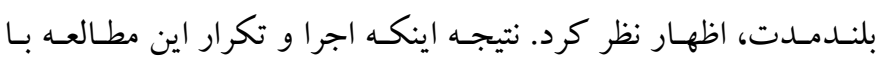

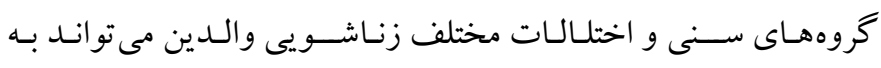
تعميمدهى و دقت نتايج به دسـت آمده بيفزايد. براى مثال علاوه بر تأثير

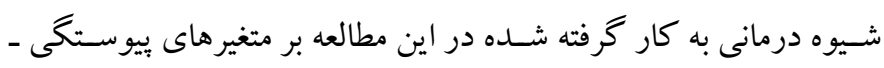

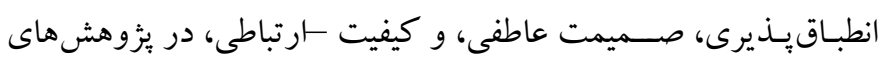

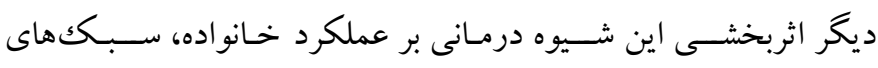

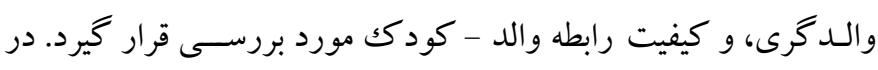

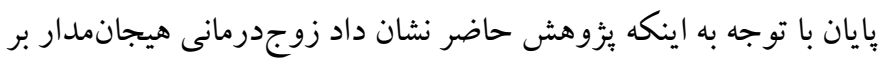

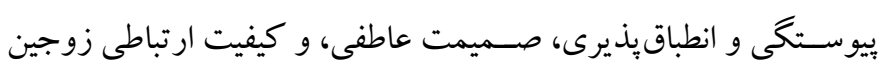

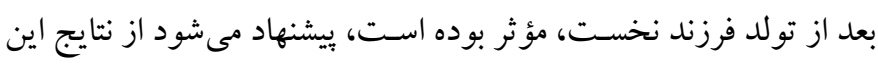

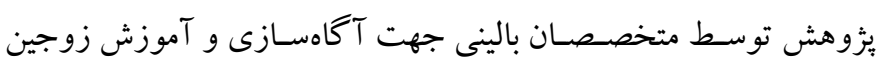

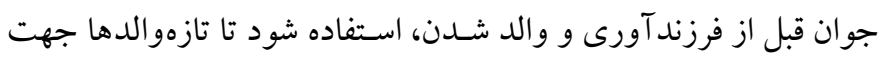
سازش يافتكى با كشاكش هاى جديد والد شدن، آماده باشند.

\section{ملاحظات اخلاقى}

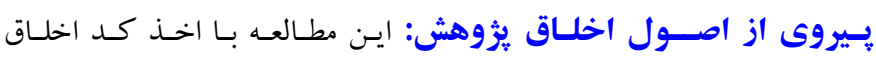
3999.254، IR.GUMS.REC.

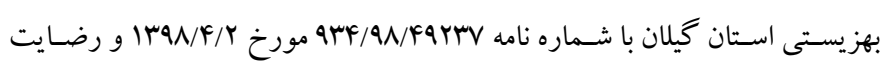
كامل افراد نمونه، انجام شده است. حامى مالى: اين مطالعه بدون حامى مالى و در قالب رساله دكترا انجام شده است.

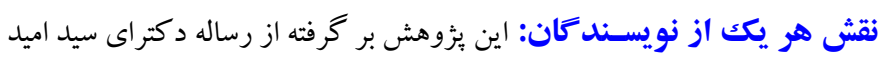

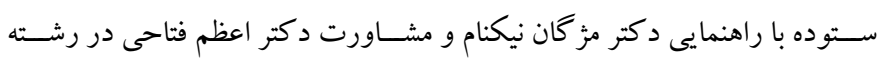

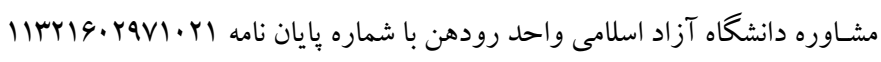

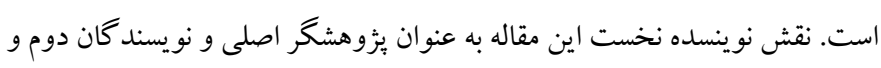

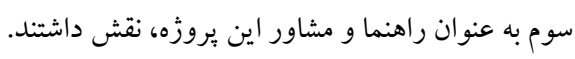

زوجين كمكك مى كند با توجه به ناتوانى در بردازش شــناختى اطلاعات

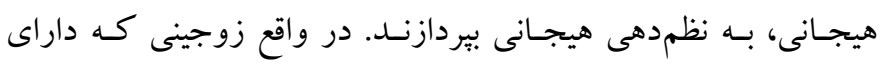

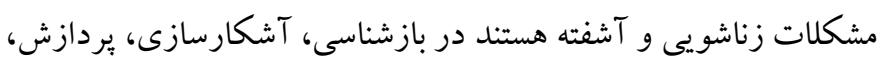

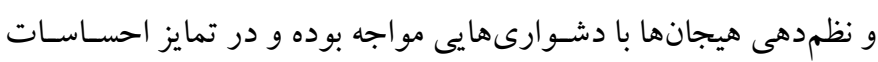

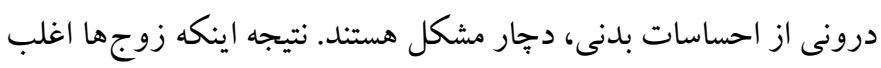
در جريان آشـتخى هاى هيجانى خاصى وارد درمان مىشـوند و سطوح

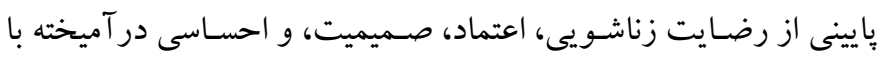

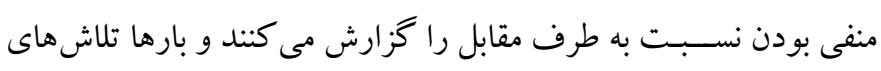

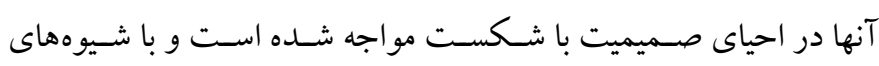

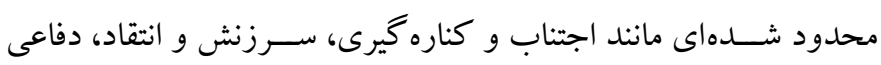
بودن و جرخهـهاى دفاعى با هم ارتباط برقرار مى كنند. بنابراين در فرايند

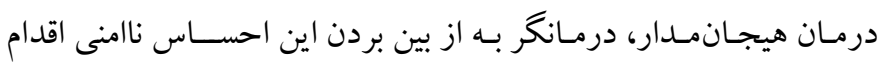

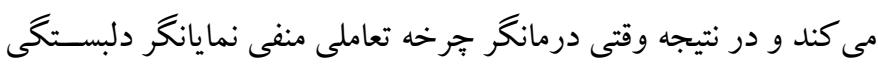

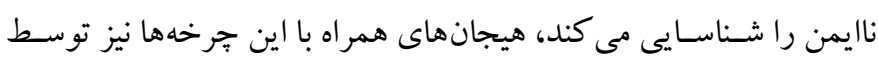

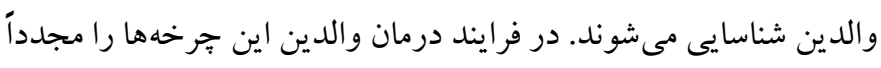

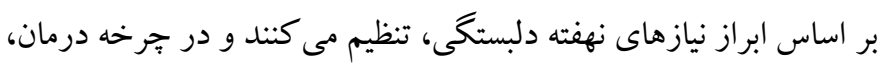

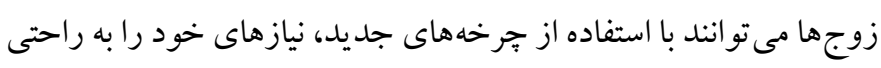

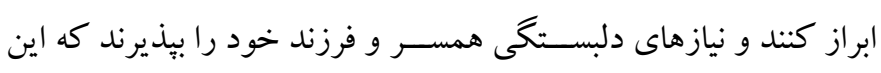
موضوع باعث كاهش نارسايى هيجانى والدين مى شود. بنابر اين هدف از از

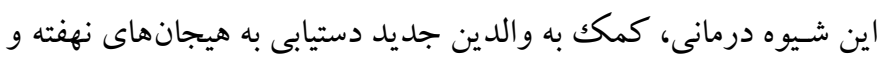

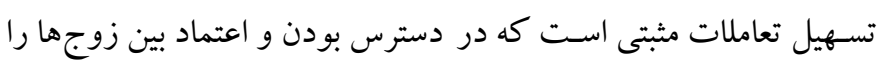
افز ايش مى دهد. يافته هاى بثزوهشى زاكارينى، جانسون، دالخيش و مكينان (سr) نشان

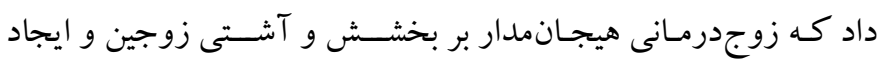

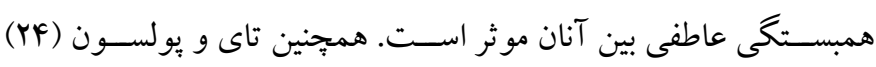

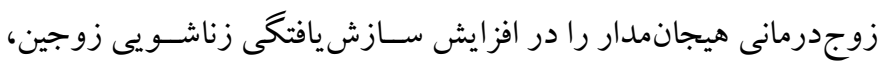

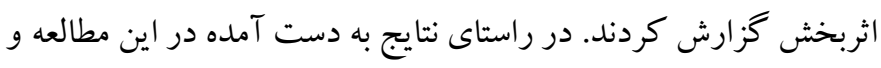

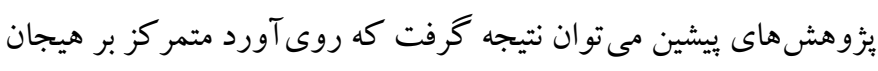

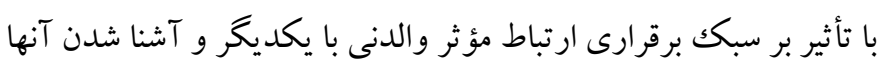

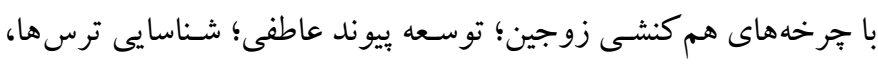

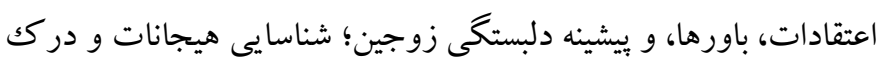

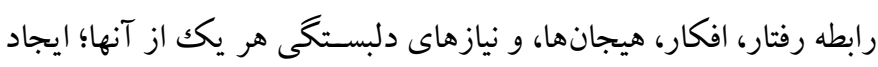


تشـكر و قدردانى: بدين وسـيله از تمامى افراد نمونه جهت شركت در انجام اين

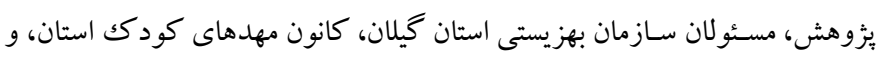

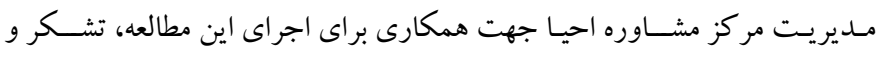

$$
\text { قدردانى مى شود. }
$$

تضــاد منافع: انجام اين بزووهش بر اي نويسـند گان هيج گونه تعارض منافع را به

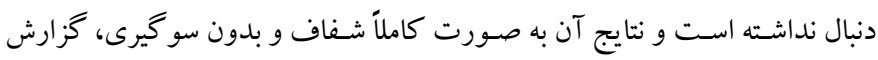
شده است. 


\section{References}

1. Martins C. A. Transition to parenthood: consequences on health and well-being. A study. Enferm Clin. 2018. [Link]

2. Bash A. R. A treatment model for marital satisfaction in couples with young children. A dissertation submitted to the Faculty of The Chicago School of Professional Psychology in partial fulfillment of the requirements for the degree of doctor of Philosophy in Psychology in Applied Clinical Psychology. 2016. [Link]

3. Wallace P. M \& Gotlib I. H. Marital Adjustment during the Transition to Parenthood: Stability and Predictors of Change. Journal of Marriage and the Family. 1990; 52(1): 21-29. [Link]

4. Sevinç M \& Garip E. S. A study of parents' child raising styles and marital harmony. Procedia Social and Behavioral Sciences. 2010; 2:1648-1653. [Link]

5. Wittenborn K, Ridenour A, MitchellRyan A \& Seedall B. Randomized controlled trial of emotionally focused couple therapy compared to treatment as usual for depression: Outcomes and mechanisms of change. Journal of Marital and Family Therapy.2018; 45: 395409. [Link]

6. Bartolo G, Benedetto L \& Ingrassia M. Couple's wellbeing and parenting in the transition to parenthood: what are the gender differences? Interdisciplinary Journal of Family Studies. 2013; 18(1): 30-50. [Link]

7. Matysiak A, Mencarini L \& Vignoli D. Work-family conflict moderates the relationship between childbearing and subjective well-being. European Journal of Population. 2016; 32(3): 355-379. [Link]

8. Schwartz AL. Marital quality, acculturation, and communication in Mexican American couples. [Dissertation]. Utah State University, Logan, Utah. 2011. [Link]

9. Vazhappilly J.J \& Reyes M.E.S. Efficacy of emotion-focused couple's communication program for enhancing couples' communication and marital satisfaction among distressed partners. Journal of Contemporary Psychotherapy.2017; 48(2): 79-88. [Link]

10. Prager K.J \& Roberts L. Deep Intimate Connection: Self and Intimacy in Couple Relationships. In Mashek, D. and Aron, A. (Eds.) The Handbook on Closeness and Intimacy. Lawrence-Ehrlbaum. 2008. [Link]

11. Pielage S, Luteinjin F \& Arrindell W. Adult attachment, intimacy and psychological distress in a clinical and community sample. Clinical Psychology and Psychotherapy. 2005; 12: 455- 464. [Link]
12. Olson D. H. FACES IV and the Circumplex Model: Validation study. Journal of Marital and Family Therapy. 2011; 37(1): 64-80. [Link]

13. Mühlenbeck C, Pritsch C, Wartenburger I, Telkemeyer S and Liebal K. Attentional Bias to Facial Expressions of Different Emotions - A Cross-Cultural Comparison of Akhoe Haiom and German Children and Adolescents. Front. Psychol. 2020: 11:795. [Link]

14. Vandeleur CL, Jeanpretre N, perrez M, schoebi D. Cohesion, satisfaction with family Bonds, and Emotional Well-Being in families with Adolescents. Journal of Marriage and Family. 2009; 17: 1205-121. [Link]

15. Bozorgmanesh K, Nazari A \& Zahrakar K. Effectiveness of family therapy on its cohesion and flexibility. Journal of Holistic nursing and midwifery. 2016; 26(4):27-35. [Link]

16. Trillingsgaard T, Baucom K. J. W \& Heyman R. E. Predictors of change in relationship satisfaction during the transition to parenthood. Family Relations. 2014; 6: 667-679. [Link]

17. Trillingsgaard T, Baucom K. W, Heyman R. E \& Elklit A. Relationship interventions during the transition to parenthood: Issues of timing and efficacy. Family Relations. 2012; 61: 770 - 783. [Link]

18. Jones D. E, Feinberg M. E, Hostetler M. L, Roettger M. E, Paul I. M \& Ehrenthal D. B. Family and child outcomes 2 years after a transition to parenthood intervention. Family Relations. 2018; 67: 270-286. [Link]

19. Johnson S. M. Attachment in action. Changing the face of 21st century couple therapy. Current Opinion in Psychology.2019; 25: 101-114. [Link]

20. Wiebe S.A, Johnson S.M, Lafontaine M.F, Burgess M.M, Dalgleish T.L, Tasca GA. Two-Year Follow-up Outcomes in Emotionally Focused Couple Therapy: An Investigation of Relationship Satisfaction and Attachment Trajectories. J Marital Fam Ther. 2017; 43(2):227-244. [Link]

21. Welch S, Lachmar E, \& Wittenborn K. Establishing safety in emotionally focused couple therapy: A single-case process study. Journal of Marital and Family Therapy. 2019; 45: 402-415. [Link]

22. Philipp A, Lee J ,Stamm T, Wininger M, Datler W. Co-parenting Intervention for Expectant Parents Affects Relationship Quality: A Pilot Study, Tohoku J. Exp. Med. 2020; 252: 33-43. [Link]

23. Zuccarini D, Johnson S.M, Dalgeish T.L \& Makinen J.A. Forgiveness and Reconciliation in Emotionally Focused Therapy for Couples: The Client Change 
Process and Therapist Interventions. Journal of Marital Fam Ther.2013; 39(2): 148-62. [Link]

24. Tie S \& Poulsen Sh. Emotionally focused couple therapy with couples Facing Terminal Illness. Contemp Fam Ther. 2013; 35:557-567. [Link]

25. Khojastemehr R, Abaspoor Z, Rajabi R. The comparison of Cohesion, Adaptability, communication and marital satisfaction in high forgiving and low forgiving married employees in Ahvaz offices, journal of education and psychology. 2008; 15(1):179-194.[ Link]
26. Schaefer M.T \& Olson D.H. Assessing intimacy: The pair inventory. Journal of marital and family therapy. 1981; 7: 47-60. [Link]

27. Khojastemehr R, Ahmadi A, Sodani M \& Shiralinia Kh. Effectiveness of brief integrative couples counseling on emotional intimacy and marital quality of couples. Contemporary Psychology. 2016; 10(2): 29-40. [Link]

28. Khoshkam s, Ahmadi A \& Abedi M.R. The effect of communication Training on couples relationship in Isfahan. Counseling research and development. 2008; 6(24): 123-136. [Link] 